\title{
Düzce bölgesi taşkın duyarlılık alanlarının belirlenmesi
}

\author{
Esin 0ğuz ${ }^{1}$, Kahraman 0ğuz ${ }^{*} @$, Kurtuluş Öztürk1® \\ 1Meteoroloji Genel Müdürlüğü, Tahminler Dairesi Bașkanlığı, Ankara, Türkiye \\ ${ }^{2}$ Meteoroloji Genel Müdürlüğü, Araştırma Dairesi Başkanlığı, Ankara, Türkiye
}

\author{
Anahtar Kelimeler \\ Düzce Bölgesi \\ Taşkın Modellemesi \\ Taşkın Duyarlılık Alanları \\ Coğrafi Bilgi Sistemleri \\ Analitik Hiyerarşi Yöntemi
}

\begin{abstract}
Öz
Son yıllarda ülkemizde sıkça yaşanan taşkın olayları, önemli can ve mal kayıplarına sebep olmaktadır. Düzce bölgesi, coğrafi yapısı nedeniyle taşkın olaylarının sıkça yaşandığı bölgelerden birisidir. Bu çalıșmada, yağıșa bağlı tașkın duyarlılık alanlarındaki değișimi görmek amacıyla iki farklı koşula göre Düzce bölgesinin taşkın duyarlılık alanları modellenmiștir. Çalıșmanın ilk aşamasında, uzun yıllar yağıș ölçüm verilerine göre taşkın duyarlılık alanları modellenmiştir. İkinci aşamada ise, Düzce'de 17-18 Temmuz 2019 tarihinde gerçekleșen taşkına ait yağış verileri ile tekrar modelleme yapılmıștır. Bu yolla, hem uzun yıllar yağış verilerine göre, hem de taşkın olayının gerçekleştiği güne ait yağış verileri ile taşkın duyarlılık haritaları üretilerek aradaki değișim karşılaştırılmıștır. Çalışmada yağış verilerinin dıșında eğim, bakı, akarsuya uzaklık, jeoloji, arazi kullanım ve toprak haritaları gibi diğer sayısal haritalardan yararlanılmıștır. Modelleme yapılırken son yıllarda sıkça kullanılan Çok Kriterli Karar Verme Yöntemlerinden biri olan Analitik Hiyerarşi Yöntemi kullanılmıștır. Bu yönteme göre öncelikle taşkına duyarlılık durumları göz önünde bulundurularak haritalara ağırlık dereceleri işlenmiştir. Sonrasında haritalar üst üste çakıştırılarak her iki senaryo için ayrı ayrı modelleme aşaması gerçekleștirilmiştir. Çalışmanın sonucunda, ÇKKV-AHY gibi istatistiksel yöntemler, CBS teknikleri ve radar ürünleri ile yapılan tespitlerin gerçekleșen taşkın hadiselerinin analizinde kullanılabilir olduğu görülmüştür.
\end{abstract}

\section{Determination of flood susceptibility areas of Düzce region}

\section{Keywords}

Düzce Region

Flood Modeling

Flood Susceptibility Areas

Geographical Information Systems

Analytical Hierarchy Method

\begin{abstract}
Frequent flood events have been causing remarkable loss of life and property in Turkey in recent years. Düzce is one of the regions where flood events are frequently experienced due to its geographical structure. In this study, flood susceptibility areas in Düzce region are modeled with two different conditions in order to investigate the changes in the flood susceptibility areas due to precipitation. In the first stage of the study, flood susceptibility areas are modeled by using long -term records of rainfall data. In the second stage, remodeling is done by employing the rainfall data of the flood event occurred on 17-18 July 2019 in Düzce. Long-term rainfall amount and the rainfall amount measured during the flood event are obtained and the variation between them is investigated. In addition to rainfall data, other digital maps such as slope, aspect, distance to stream, geology, land use and soil maps are used in the study. Analytical Hierarchy Method, which is one of the Multi-Criteria Decision Making Methods that has been used frequently in recent years is selected and the degrees of gravity are recorded on the maps by considering the flood susceptibility. The maps are overlapped and the modeling phase is carried out separately for both scenarios. As a result of the study, it is depicted that the results obtained by means of GIS techniques, weather radar products as well as statistical methods such as Multi-Criteria Decision Making Methods, can be used efficiently in the analysis of flood events.
\end{abstract}




\section{Giriş}

Tașkınlar; uzun süreli şiddetli yağışlar, heyelanlar, kar erimesi, barajlar ve/veya depolanma tesislerinden kontrolsüz su bırakılması, nehir yataklarının kontrolsüz kentleşmeye açılması sonucu akarsu yataklarının daralması gibi nedenlerle, yerleşim alanlarına, çevre arazilere, alt yapı tesislerine zarar vererek, taşkının meydana geldiği bölgede sosyal ve ekonomik faaliyetlerin kesintiye uğramasına sebep olan, canlı hayatını olumsuz yönde etkileyen maddi ve manevi kayıplara sebep olan doğal afet çeșitlerinden biridir (Demir ve Keskin, 2021). Son yıllarda ülkemizde sıklıkla görünen taşkınlar, önemli maddi ve manevi kayıplara yol açan doğal afet çeşitlerinden birisidir. Hidrometeorolojik afetlerin etkisi ve şiddeti son ylllarda giderek artmaktadır. İlerleyen yıllarda da küresel iklim değişikliğinin ve artan çarpık kentleşmenin etkisiyle, hidro-meteorolojik afetlerde daha fazla artışlar beklenmektedir (Kadıoğlu ve Özdamar, 2008). Bu durumun ekonomik kayıpları beraberinde getirmesi de kaçınılmazdır. Türkiye İklim Değişikliği Risk Yönetimi Raporu, iklim değişikliği nedeniyle ülkemizde görülen sellerin sebep olduğu ekonomik kayıpların, depremler sebebiyle gerçekleşen ekonomik kayıplara eşit olduğunu vurgulamaktadır (Kadığlu, 2012). Küresel iklim değişikliğinin etkileri, iklim kuşaklarının kayması, hava sıcaklıklarında artışların olması, buzulların erimesi, buzulların erimesine bağlı deniz seviyelerinde yükselme olarak bilinse de, bu etkenlerin beraberinde getirdiği şiddetli fırtınalar ve yağışlar gibi meteorolojik hadiseler sonucu taşkın ve sel hadiselerinin şiddeti ve sıklığında artış görülmektedir. Atmosferdeki nem, yağışı etkileyen bir parametredir ve hava sıcaklıklarındaki artış ile birlikte atmosferdeki nem miktarı da artar. Özalp (2009) tarafından belirtildiği üzere, Karadeniz ve Akdeniz sahillerinde olduğu gibi nemli hava akışına dik yüksek rakımlı alanlarda şiddetli yağışlar ve büyük taşkınlar oluşur. Yağış parametresi taşkını etkileyen önemli bir etken olmasına rağmen, hatalı arazi kullanımı, akarsu yataklarının ve havza özelliklerinin tahribatı gibi olaylar da yaşanabilecek taşkınların büyüklüğünü etkilemektedir. Bunun yanında akarsular üzerine inşa edilen bazı yapılar, riskli olmayan özelliklerin riskli olarak analiz edilmesine sebep olmaktadır. Bu ise, akarsu yataklarında arazi kullanımı açısından yapılacak risk yönetimi çalışmalarında bazı yeni planların dikkate alınmasına neden olmaktadır (Özdemir, 2007).

Tüm dünyada taşkın risk ve duyarlılık analizi amacıyla bazı yöntem ve araçlar geliştirilmiştir. Risk yönetimi sistematik bir süreç olup, riskin belirlenmesi, çözümlenmesi ve büyüklüguünün tespit aşamalarından oluşur. Taşkın bölgelerinde risk yönetimi altında gerçekleştirilecek çalışmalar, özellikle taşkının sebep olacağı olumsuzlukları en aza indirmek, can ve mal kayıplarını önlemek için önemlidir. Taşkın risk yönetimi çalıșmaları içerisinde, taşkın açısından riskler tespit edilmekte, senaryolar hazırlanmakta, zarar azaltma önlemleri seçilmekte, elde edilen analizler harita ve grafiklerle gözler önüne serilmekte, kullanılması muhtemel imkanlar tespit edilmekte ve sonrasında afet müdahalesi açısından optimum seçenekler hakkında karar alınıp uygulamaya konulmaktadır (Özcan ve ark., 2009). Duyarlılık analizi de riski belirleme yöntemlerinden birisidir.

Dünyada taşkın analizi amacıyla geliștirilen en önemli araçlardan bir tanesi Coğrafi Bilgi Sistemleridir (CBS). CBS, son yıllarda özellikle risk ve duyarlılık analizlerinde sıkça kullanılmaktadır. Bu aracı cazip kılan en önemli etkenlerden bir tanesi, uzaktan algılama ve CBS teknolojilerinin bir arada ve büyük bir coğrafyada kullanılabilir olmasıdır.

Uzun yıllardan beri taşkın risk ve duyarlılığına yönelik olarak çeşitli çalışmalar yapılmıştır. Ancak, Düzce bölgesi için yapılmış bir taşkın duyarlılık çalışması bulunmamaktadır. Bu çalışmada, Düzce ilinin farklı yağış koşulları göz önünde bulundurularak taşkın duyarlılık alanlarını belirlemek amacıyla; yer gözlemleri, meteorolojik radar ürünleri ve CBS teknolojisi ile havzaya ait morfolojik özellikler belirlenmiş ve havza karakteristik özelliklerine göre farklı senaryolar göz önüne alınarak çeşitli taşkın duyarlılık haritaları oluşturulmuştur.

\section{Yöntem}

\section{1. Çalışma alanı ve başlıca özellikleri}

Çalışma alanını içeren Düzce ili, Karadeniz Bölgesi'nin batısında yer almaktadır. Düzce havzasının ortasında $360 \mathrm{~km}^{2}$ genişliğinde Düzce Ovası, doğusunda Bolu Dağları, batısında Sakarya, kuzeyinde Orhan Dağları ve Karadeniz, güneyinde ise Abant dağları bulunmaktadır (Özaslan ve ark., 2001). Düzce ilinde çoğunlukla Karadeniz iklimi hâkim olmaktadır. Coğrafi yapısı nedeniyle yoğun yağış almaktadır. Bölgede en fazla yağış, sonbahar ve kış aylarında görülmektedir. Yaz ayları ise sıcak ve az yağışlı geçmektedir. Düzce ilinin yıllık sıcaklık ortalaması $13-14^{\circ} \mathrm{C}$, yıllık toplam yağış ortalaması ise $830 \mathrm{~mm}$ civarındadır. Yılın ortalama 144 günü yağışlı geçmektedir (MGM, 2021a).

Düzce havzası dik yamaçlı ve çevre kaynakları düze yakın ova tabanı topoğrafyası nedeniyle, hemen hemen bütün havza kenarlarında alüvyon yelpazesi olmuştur. Havzadaki akarsular ise fazlaca bükümlü ve menderesli kanallıdır. Akarsular alüvyon yelpazelerinin dış kısımlarının ortalama yatak eğimleri ile Efteni Gölü arasında düşük kot farkı bulunuşu, akarsu yataklarının çok sı̆̆ kalmasına sebep olmaktadır. Bu drenaj özellikleri Düzce havzası için taşkın-sellenme riski olușturur (Özaslan ve ark., 2001).

Batı Karadeniz havzasında yer alan Düzce bölgesinde, özellikle Düzce il merkezi, Gümüşova, Çilimli, Cumayeri, Gölyaka ilçelerinin bulunduğu alanda yüksekliğin deniz seviyesine kadar indiği ve eğimin azaldığı, çalışma alanının diğer alanlarında ise yükseklikle birlikte eğimin arttığı görünmektedir. Şehirleşmenin yoğun göründüğü Düzce merkezi ve çevre ilçelerinin çevresindeki yüksek dağların varlığı ile birlikte yerleșim yerlerinin deniz seviyesi yüksekliğinde ve eğimin düşük olması, zemin ve arazi kullanım özellikleri nedenleriyle birlikte şehirleşmenin büyük ölçüde havza su toplama alanında olması, yağış ile beraberinde bölgede taşkın olaylarına sebep olmaktadır. 
Çalışma alanı, Düzce il merkezi ve ile bağlı Akçakoca, Kocaali/Melen, Çilimli, Cumayeri, Gölyaka, Yığılca, Kaynaşlı ve Hendek ilçelerinin bulunduğu havzayı kapsamaktadır (Şekil 1). Çalıșma alanı, seçili il ve ilçeler ve dahil olduğu havzalar dikkate alınarak, CBS teknolojilerinden biri olan ArcGIS 10.3 programında ile
Arazi Verilerini Ön İşleme (ArcHydro Terrain Preprocessing), Su Toplama Alanını Poligonlama (Catchment Polygon Processing) yöntemiyle çizdirilerek belirlenmiștir. Havza alanı belirlenirken $10 \mathrm{~m}$ Sayısal Yükseklik Modeli (Digital Elevation Model- DEM) verisi kullanılmıştır.

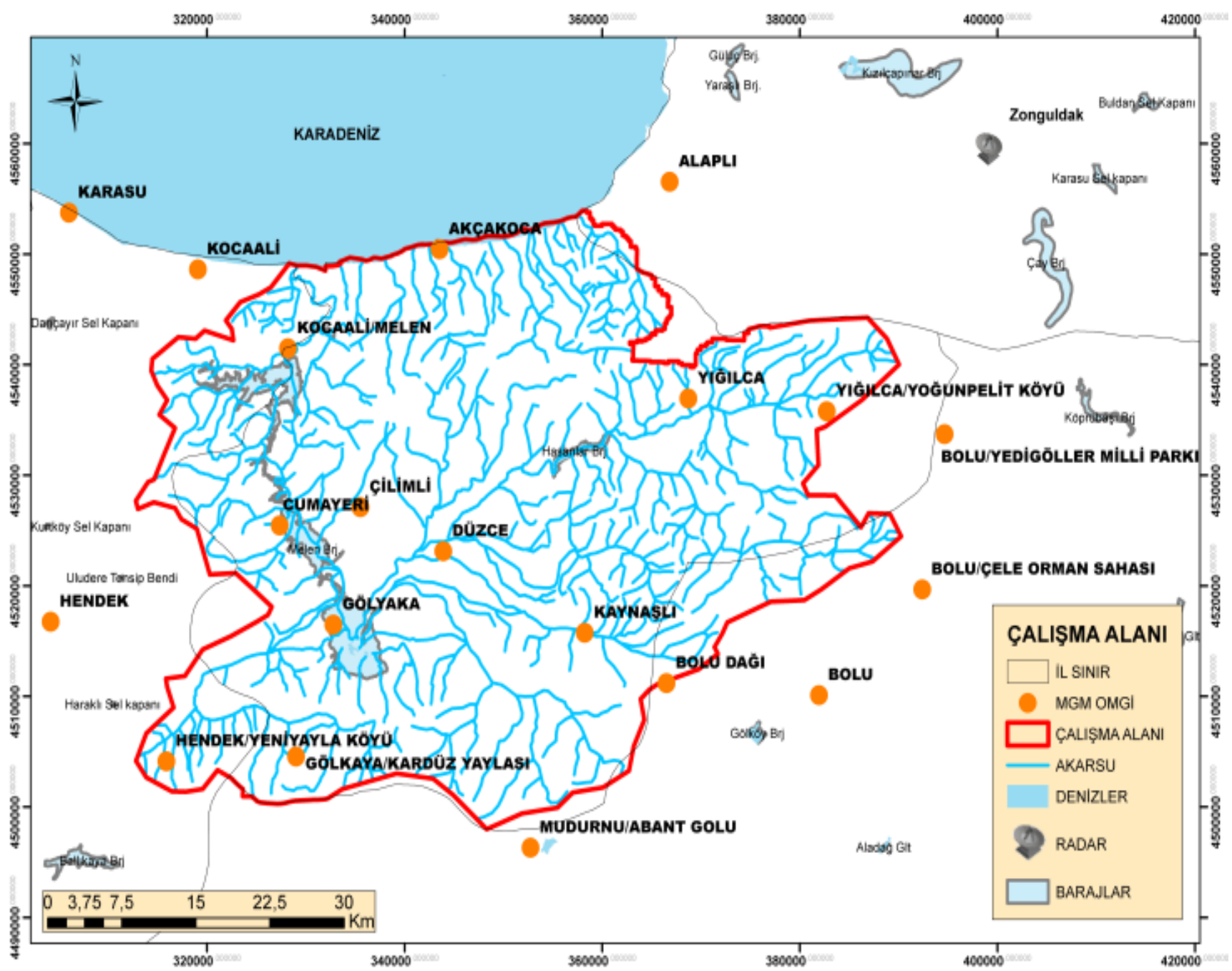

Şekil 1. Çalışma alanı

\subsection{Araștırmanın modeli}

Calıșmada Çok Kriterli Karar Verme (CKKV) yöntemi kullanılmıştır. ÇKKV, birden çok ve uyum içerisinde olmayan kriterleri barındıran ve bu duruma modelleme yaklaşımıyla bir çözüm sağlayan süreci tanımlar. ÇKKV hayatın pek çok alanında yaygın olarak kullanılan bir yöntemdir (Baysal ve Tecim, 2006). ÇKKV yönteminin temel amacı, fazla sayıda kriterlerin varlığı durumunda, tüm seçenekleri göz önünde bulundurarak süreci kontrol altında tutmak ve hızlı bir şekilde çözüme ulașmaktır (Öztürk, 2009). CBS ortamında kullanılabilen birçok ÇKKV yöntemi bulunmaktadır. Bu çalışmada, en sık kullanılan yöntemlerden birisi olan Analitik Hiyerarşi Yöntemi (AHY) kullanılmıştır. AHY, fazla sayıda alternatifin ve karar vericilerin varlığı durumunda, ele alınan kriterlere göre karar verme amacıyla kullanılır. Kriter seviyeleri ve hiyerarşik seçenekler içeren AHY, karar üzerinde etkisi bulunan parametreler açısından kararların yüzde dağılımlarını göz önüne alan bir karar verme ve modelleme yöntemidir (Özcan, 2017).

AHY'nin ilk aşaması, problemin hiyerarşik yapılandırmasını içermektedir. $\mathrm{Bu}$ aşamanın temel amacl, karar verme problemini alt öğelere ayırmak ve bu öğelerin birbiriyle ilișkilerini göz önüne seren bir modelleme yapmaktır. Sonrasında bu öğeler gruplandırılarak hiyerarșik bir yapı tasarlanır. AHY'nin ikinci aşamasında; bir karşılaştırmanın yapılabilmesi amaciyla tercih matrisleri olușturulur. Bu matris nxn boyutundadır. Matrisin köșegen bileşenleri $i=j$ olması durumunda, 1 değerini alır. Parametreler arası karşılaştırma işlemi, aralarındaki önem durumlarına göre karşılıklı olarak yapılır (Özcan, 2017; Yaralığlu, 2004). İkili karşılaştırma yöntemi, çoklu grupların birbirleri ile olan ilişkilerini değerlendirdiğinden, karar verme konusundaki karıșıklığın azaltılmasını sağlamaktadır (Erten ve Coşkun, 2010). Son aşama olarak ise, faktörlerin önem dereceleri belirlenir, 
ağırlıklı çakıştırma analizi ile katmanlar toplanır ve sonuç dağılımları bulunur.

Çalışmada, CBS araçlarından biri olan ArcGIS 10.3 yazılımı kullanılmıştır. Veri seti olarak, 1/25000'lik ölçekli Topografya haritalarından üretilen sayısal yükseklik modeli, eğim, bakı, yağıș, jeoloji, toprak, arazi kullanım ve akarsuya olan uzaklık haritaları; yöntem olarak ise ÇKKV Yöntemlerinden biri olan AHY kullanılmıştır. Tüm bu harita katmanları, CBS ortamında alt sınıflara ayrılarak, tașkının gerçekleşmesindeki etki durumlarına göre ağırlık dereceleri verilmiș ve sonrasinda bu katmanlar üst üste getirilerek (toplanarak) taşkın duyarlılık alanları tespit edilmiştir.

Tablo 1. Taşkın Duyarlılığına İlişkin Parametrelerin Önem ve Hiyerarşik Yapısı

\begin{tabular}{|c|c|c|}
\hline \multirow{7}{*}{$\begin{array}{l}\text { JEOLOJI } \\
\text { (A.D: 5) }\end{array}$} & PALEOSEN (GRAIINOYIDLER) & A.D: 8 \\
\hline & EOSEN (KIRINTILAR, YER YER KARASAL) & A.D: 9 \\
\hline & PALEOSEN-EOSEN (GRAIINOYIDLER) & A.D: 5 \\
\hline & VOLKANİTLER VE SEDİMENTER KAYALAR & A.D: 9 \\
\hline & ÜST KRETASE (DASİT, RIYYOLİ, RİYODASİT) & A.D: 4 \\
\hline & $\begin{array}{l}\text { ÜST KRETASE-EOSEN (NETRİT KİREÇ TAŞLARI, KIRINTILAR } \\
\text { VE KARBONATLAR) }\end{array}$ & A.D: 2 \\
\hline & ÜST PALEOSEN-EOSEN (KIRINTILAR VE KARBONATLAR) & A.D: 2 \\
\hline \multirow{7}{*}{$\begin{array}{c}\text { ARAZİ KULLANIM } \\
\text { (A.D: } 5 \text { ) }\end{array}$} & SU YOLLARI, DENIZZ VE OKYANUS & A.D: 2 \\
\hline & LIMMANLAR, MINERAL ÇIKARIM SAHALARI, İNŞAAT SAHALARI & A.D: 7 \\
\hline & $\begin{array}{l}\text { GENIŞ YAPRAKLI ORMANLAR, KARIŞIK ORMAN, KESIKLİ ŞEHİR, } \\
\text { İĞNE YAPRAKLI ORMANLAR }\end{array}$ & A.D: 1 \\
\hline & ÇIPLAK KAYA & A.D: 7 \\
\hline & SULANMAYAN KARIŞIK TARIM & A.D: 2 \\
\hline & DOĞAL BİTKİ ÖRTÜSÜ İLE BİRLIKTE TARIM ALANLARI & A.D: 2 \\
\hline & $\begin{array}{l}\text { BİTKİ DEĞİŞIM ALANLARI, DOĞAL ÇAYIRLIKLAR, } \\
\text { SEYREK BİTKİ ALANLARI }\end{array}$ & A.D: 3 \\
\hline \multirow{5}{*}{$\begin{array}{l}\text { EĞİM } \\
\text { (A.D: 8) }\end{array}$} & $0^{\circ}-3^{\circ}$ & A.D: 9 \\
\hline & $3^{\circ}-10^{\circ}$ & A.D: 7 \\
\hline & $10^{\circ}-20^{\circ}$ & A.D: 5 \\
\hline & $20^{\circ}-30^{\circ}$ & A.D: 3 \\
\hline & $30^{\circ}>$ & A.D: 1 \\
\hline \multirow{7}{*}{$\begin{array}{l}\text { TOPRAK } \\
\text { (A.D: } 6)\end{array}$} & YERLEŞİM (YR) & A.D: 8 \\
\hline & ALÜVYAL TOPRAKLAR (A) & A.D: 9 \\
\hline & KAHVERENGI ORMAN TOPRAKLARI (M) & A.D: 5 \\
\hline & KOLÜVYAL TOPRAK (K) & A.D: 9 \\
\hline & KIRMIZI SARI PODZOLIK TOPRAK (Y) & A.D: 4 \\
\hline & YÜKSEK DAĞ ÇAYIR TOPRAK (Y) & A.D: 2 \\
\hline & KİREÇSİZ KAHVERENGİ ORMAN TOPRAKLARI(N) & A.D: 2 \\
\hline \multirow{5}{*}{$\begin{array}{l}\text { BAKI } \\
\text { (A.D: 7) }\end{array}$} & GÜNEY-GÜNEYDOĞU-GÜNEYBATI & A.D: 1 \\
\hline & DOĞU-BATI & A.D: 4 \\
\hline & DÜZ & A.D: 9 \\
\hline & KUZEY & A.D: 7 \\
\hline & KUZEYDOĞU-KUZEYBATI & A.D: 5 \\
\hline \multirow{9}{*}{$\begin{array}{c}\text { AKARSUYA OLAN } \\
\text { UZAKLIK } \\
\text { (A.D: } 7 \text { ) }\end{array}$} & $0-208 \mathrm{~m}$ & A.D: 9 \\
\hline & $208-430 \mathrm{~m}$ & A.D: 8 \\
\hline & $430-665 \mathrm{~m}$ & A.D: 7 \\
\hline & $665-927 \mathrm{~m}$ & A.D: 6 \\
\hline & $927-1234 \mathrm{~m}$ & A.D: 5 \\
\hline & $1234-1602 \mathrm{~m}$ & A.D: 4 \\
\hline & $1602-2032 \mathrm{~m}$ & A.D: 3 \\
\hline & $2032-2051 \mathrm{~m}$ & A.D: 2 \\
\hline & $2051-3000 \mathrm{~m}$ & A.D: 1 \\
\hline \multirow{9}{*}{$\begin{array}{l}\text { YAĞISS } \\
\text { (A.D: } 7)\end{array}$} & $0-40 \mathrm{~mm}$ & A.D: 1 \\
\hline & $40-60 \mathrm{~mm}$ & A.D: 2 \\
\hline & $60-80 \mathrm{~mm}$ & A.D: 3 \\
\hline & $80-90 \mathrm{~mm}$ & A.D: 4 \\
\hline & $90-110 \mathrm{~mm}$ & A.D: 5 \\
\hline & $110-140 \mathrm{~mm}$ & A.D: 6 \\
\hline & $140-170 \mathrm{~mm}$ & A.D: 7 \\
\hline & $170-200 \mathrm{~mm}$ & A.D: 8 \\
\hline & $200>$ & A.D: 9 \\
\hline
\end{tabular}


Uygulanan yöntemde taşkın duyarlılıkları belirlenirken ele alınan her bir parametre ayrı ayrı değerlendirmeye alınmıștır. Tașkın duyarlılığına ilișkin parametreler, önem derecesine göre 1 ila 9 arasında değişen ölçeğe göre ele alınmış ve bu kriterlere göre her birine ağırlık dereceleri verilmiştir. Ağırlık dereceleri verilirken (Özcan ve ark., 2009, Özcan, 2017, Sunkar ve Tonbul, 2010, Özşahin, 2013 ve Oğuz ve ark., 2016) tarafından yapılan çalışmalardaki derecelendirmeler göz önüne alınmıştır. Analiz aşamasında ele alınan haritalar, farklı katmanlar olarak gösterilmiştir. Devamında, haritaların toplama ișlemine tabi tutulması amaciyla, bu haritalar raster formatina dönüştürülmüştür. Sonrasında haritalar, Tablo 1'de gösterilen ağırlık oranlarına göre CBS ortamında işleme tabi tutulmuştur.

\subsection{Eğim ve bakı faktörleri}

Eğim faktörü, taşkının meydana gelmesinde önemli bir etkiye sahiptir. Eğimin fazla olduğu yerlerde toprağın suyu tutma kabiliyeti daha azdır. Bu nedenle de yağışla birlikte akışa geçen su miktarı eğimin fazla olduğu alanlarda daha fazla olur (Özcan, 2008). Eğimin az olduğu yerlerde, suyun akış hızının yavaşlaması ve suyun daha hızlı birikmesi sebebiyle tașkın duyarlılığ yüksektir. Çalışma alanının eğim haritası incelendiğinde, Düzce ovasında eğimin deniz seviyesine kadar düştüğü, ova çevresinde ise eğimin arttığı $\left(30^{\circ}>\right)$, kıyı kesimlere gidildikçe eğim oranının tekrar azaldığı görülmektedir (Şekil 2).

Bakı haritası, tașkın duyarlılığı için dolaylı etkiye sahiptir. Kuzeye bakan yamaçlar daha nemli ve su tutma kapasitesi daha düşük toprak alanları içerdiğinden, tașkın açısından daha fazla duyarlı alanlardır. Çalıșmada kullanılan bakı haritası Șekil 3'de görülmektedir. Topoğrafyanın kuzey bakılı yanları, güney bakılı yanlara göre güneşi daha fazla görmektedirler. Ayrıca, doğu bakıları sabahları daha fazla, batı bakıları ise akșamları daha fazla güneşi görmektedirler (Özcan, 2008). Çalışma alanına bakıldığında, Çilimli, Cumayeri ve Gölyaka ilçeleri ve Düzce merkezi arasında kalan alanın düzlük yapıda olduğu, geriye kalan diğer alanların bakısının kuzey yönlerinde olduğu görülmektedir.

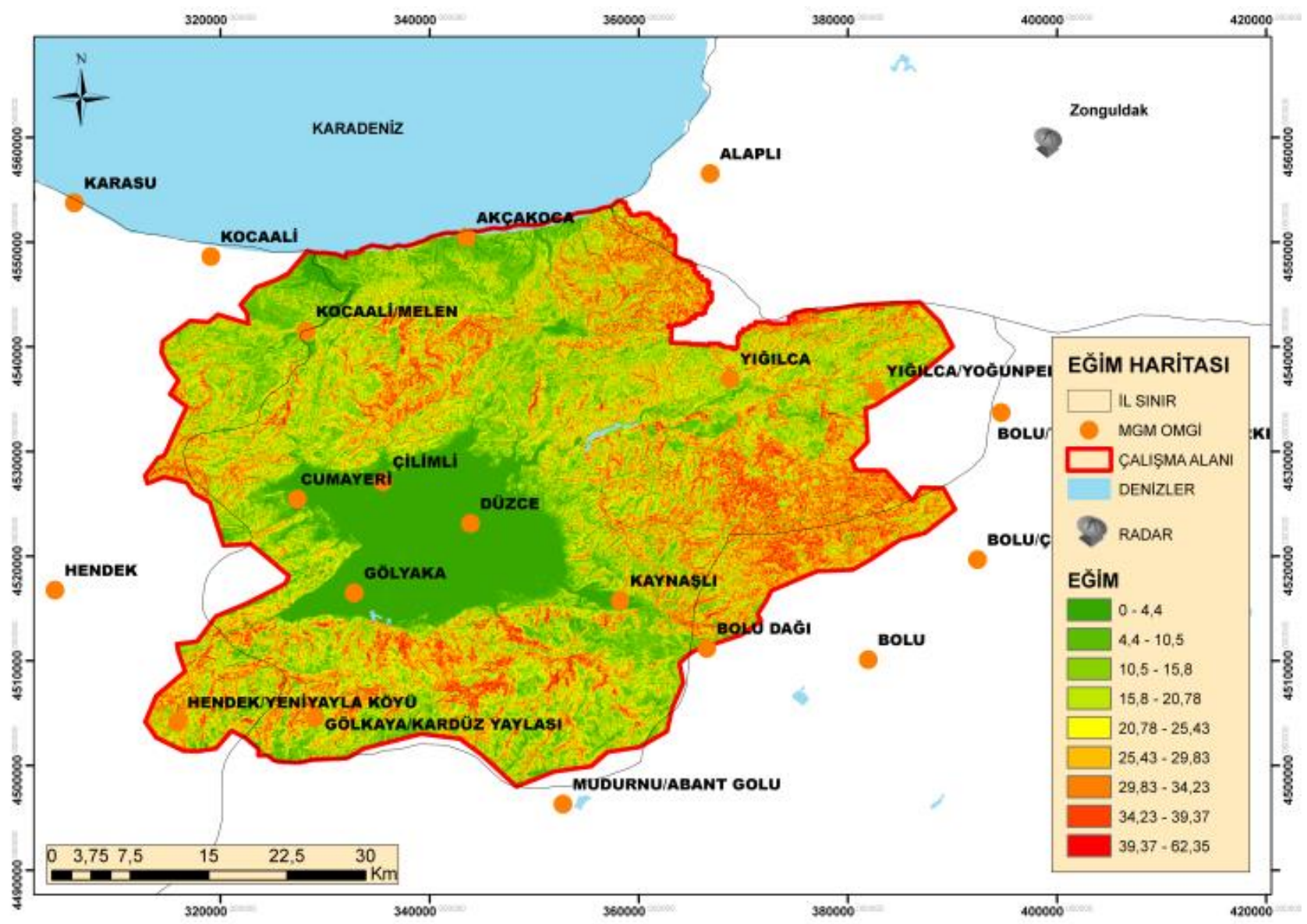

Şekil 2. Eğim Haritası 


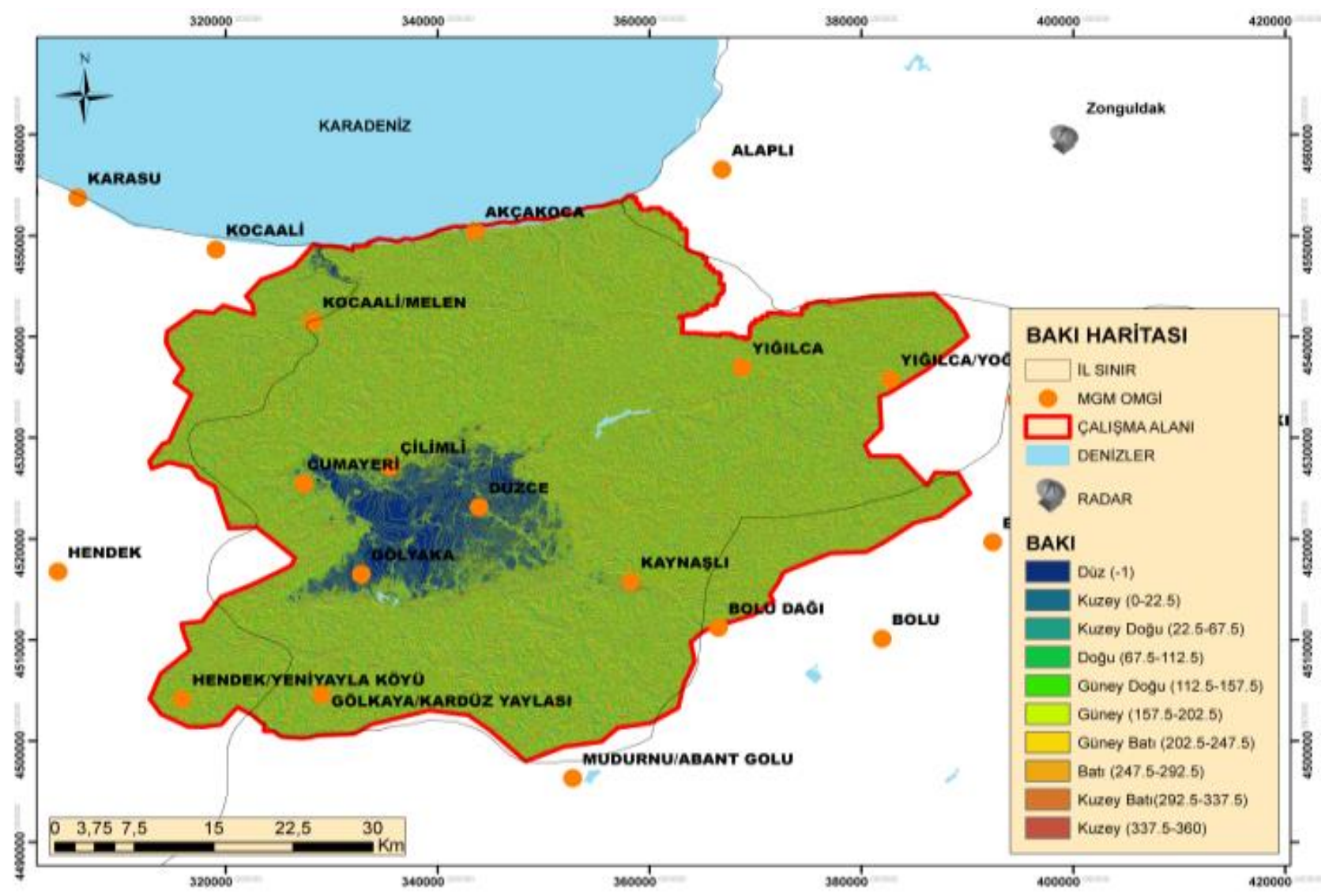

Şekil 3. Bakı Haritası

\subsection{Arazi kullanım ve toprak faktörleri}

Arazi örtüsü yer yüzeyini kaplayan bitki örtüsü, toprak, suyla kaplı alanlar ve yapay yüzeyler vb; arazi kullanımı ise araziye ilişkin insan aktivitelerini ifade eder (Öztürk, 2009; Ferreira ve ark., 2020; Jansen ve Gregorio, 2004; Li ve Yeh, 2004; Öztürk ve Batuk, 2011). $\mathrm{Bu}$ çalışmada kullanılan arazi kullanım ve toprak haritaları sırasıyla Şekil 4 ve Șekil 5'de görülmektedir. ArgGIS 10.3 programı yardımıyla görüntülenen Corine 2006 Arazi kullanım haritasına bakıldığında, çoğunluk alanın "geniş yapraklı ormanlar" ve "sulanan ve sulanmayan tarım" bölgelerinden oluştuğu görülmektedir. Bunu ise "karışık ormanlar" ile birlikte "sulanmayan meyve" takip etmektedir.

Bir toprağın ya da toprak grubunun hidrolojik özellikleri, su toplama havzasının hidrolojik analizinde temel faktördür (Özer, 1990). Toprak grupları, sızmayı farklı şekilde etkileyebilen ve dolayısıyla taşkın duyarlılığı üzerinde önemi olan bir faktördür. Çalışılan alanı toprak haritasına bakıldığında, alüvyal toprak (A), kireçsiz kahverengi toprak (N), kolüvyal toprak (K), kırmızı-sarı podzolik topraklar (P), gri-kahverengi podzolik topraklar (G) ile kaplı alanların yaygın olduğu görülmektedir. Alüvyal topraklar, akarsuların taşıdığı malzemelerden meydana gelmektedirler. Taşınır toprak olarak da bilinen alüvyal topraklar, taşkın ve sel gibi afetlere uğrayan ova gibi alanlarda sıkça görünürler. Kolüvyal toprak, dağ yamaçlarında çözünen malzemenin sel veya taşkın sularıyla dağ yamaçlarına birikmesiyle oluşan toprak türüdür. Kireçsiz kahverengi topraklar üst yüzeyi yumuşak topraklardır. Gri-Kahverengi podzolik topraklar tarım açısından verimliliği yüksek, üst yüzeyinde organik ve alt yüzeyinde minerallerin olduğu toprak türüdür. Kırmızı-Sarı podzolik topraklar ise ormanlık alanlarda görünen toprak türüdür. Çalışma alanına bakıldığında, Düzce ovasında ve denize yakın kıyı kesimlerde "A" tipi toprak miktarının fazla olduğu, kıyı kesimlerde çoğunlukla "P" tipi toprak türü alanların olduğu ve Melen, Cumayeri, Hendek, Gölyaka ve Kaynaşlı ilçelerinin bulunduğu alanlarda ise " $K$ " tipi toprakların yoğun olduğu görülmektedir.

\subsection{Jeoloji ve akarsuya uzaklık faktörleri}

Jeolojik özellikler, topografya ve yeraltı yapıları bakımından bölgeyi tanımamıza yardımcı olur ve dolaylı olarak taşkın üzerinde etkileri bulunmaktadır. Çalışma alanının ArgGIS 10.3 programı yardımıyla MTA verisinden elde edilen jeoloji haritasına bakıldığında, jeolojik özelliklerin çoğunlukla "kuvaterner", "eosen" ve "kretase-eosen" tiplerinden oluştuğu görülmektedir (Şekil 6). Kuzeydoğu ve doğu bölgelerin bazı kesimlerde ise "ordovisiyen" ve "prekambriyen" jeolojik yapılarının bulunduğu görülmektedir.

Akarsuya uzaklık faktörü de taşkın açısından diğer önemli bir faktördür (Şen, 2009). Akarsuya yakın olan yerler, taşkın duyarlılığı açısından yüksek olan yerlerdir. Çalışmada, akarsuya olan uzaklık faktörü CBS ortamında hesaplanmış ve duyarlılık sınıfları işlenmiştir. Akarsuya uzaklık faktörü haritasına; akarsuya olan $0-208 \mathrm{~m}$ uzaklık çok duyarlı, 2050 m'den fazla olan uzaklıklar ise az duyarlı olacak şekilde işlenmiş (Şekil 7). Akarsu uzaklık faktörü belirlenirken çalışllan alandaki akarsu sıklığı ve bu akarsuların yerleşim yerlerine olan uzaklıkları dikkate alınarak belirlenmiştir. 


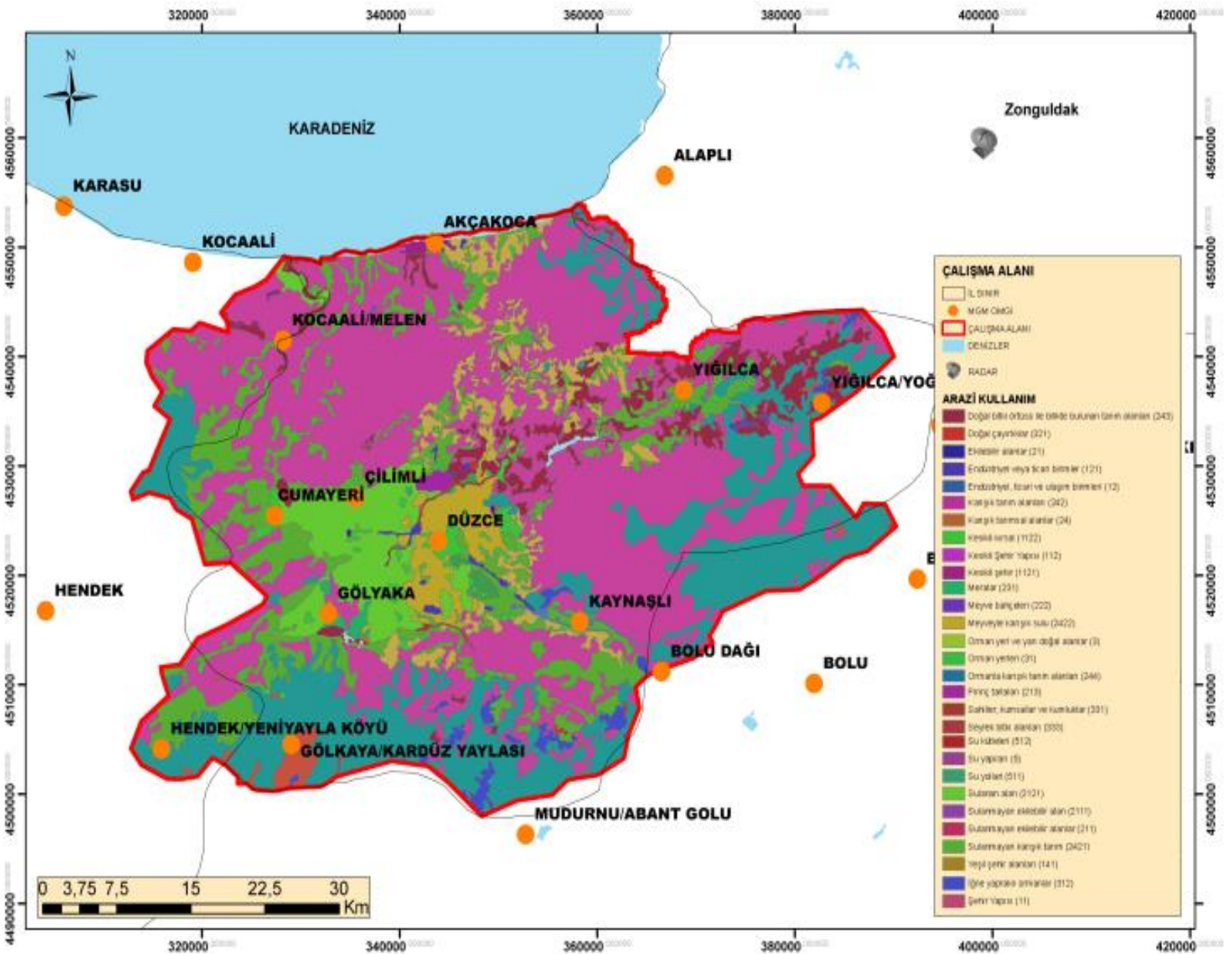

Şekil 4. Arazi Kullanım Haritası

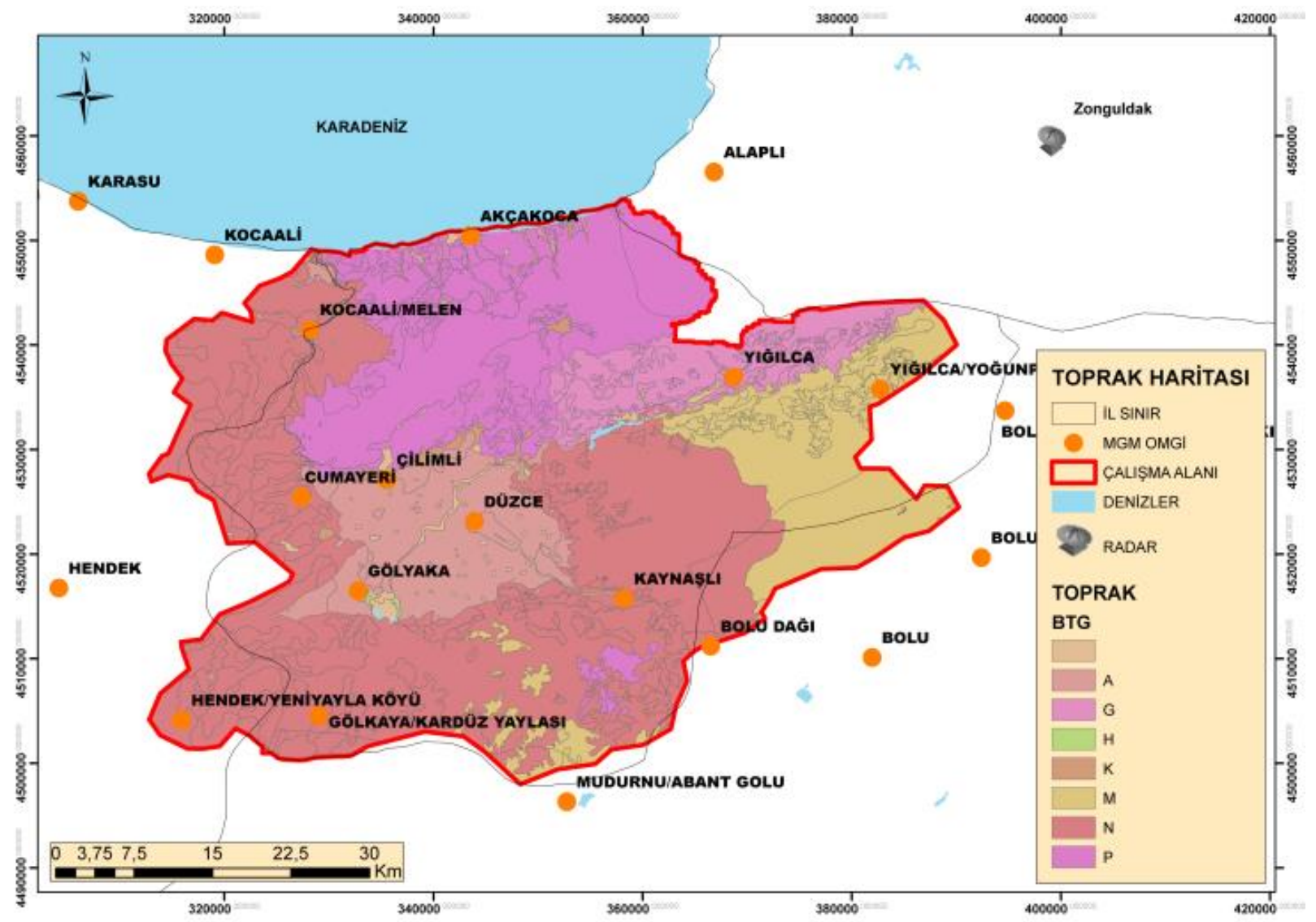

Şekil 5. Toprak Haritası 


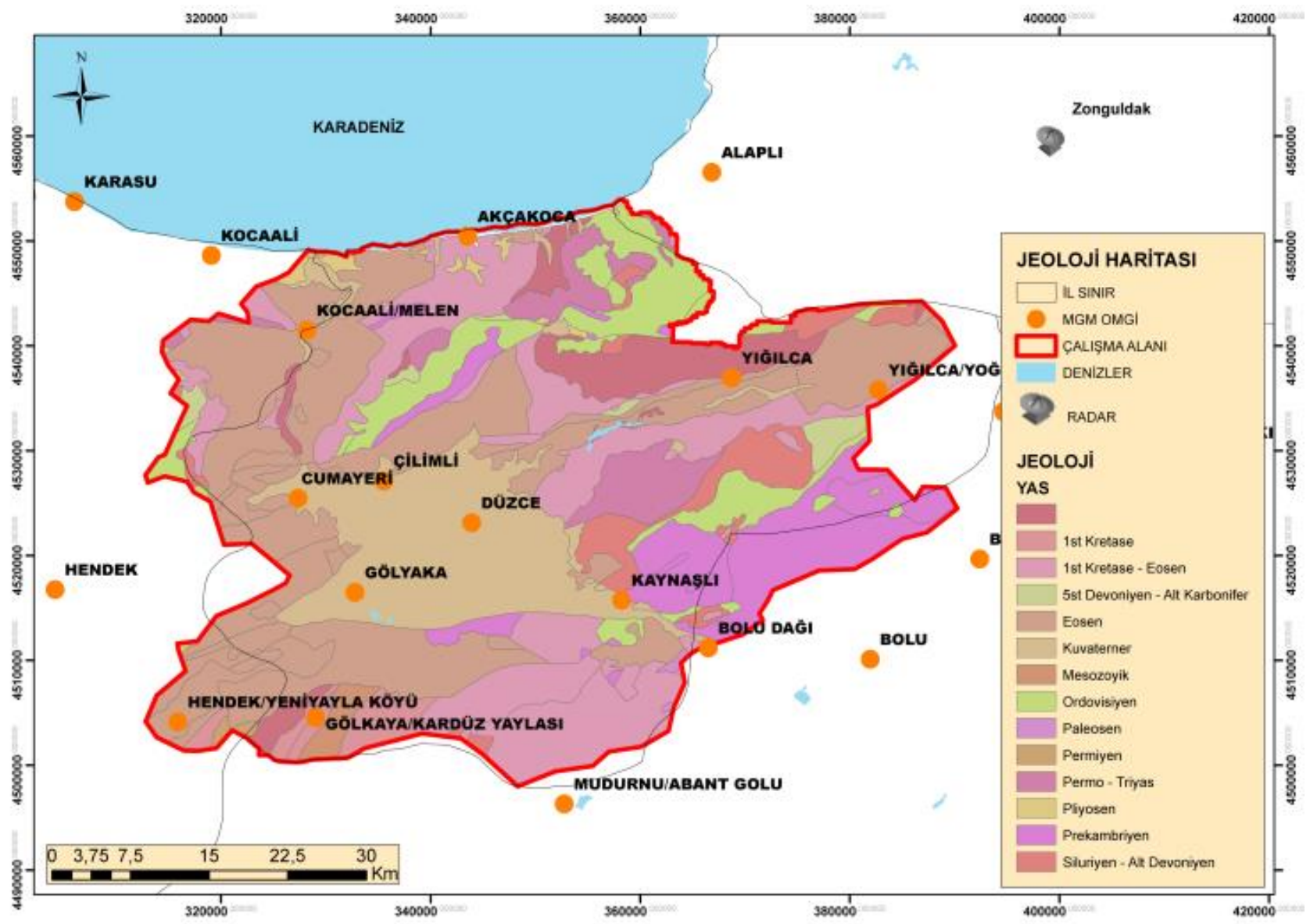

Şekil 6. Jeoloji Haritası

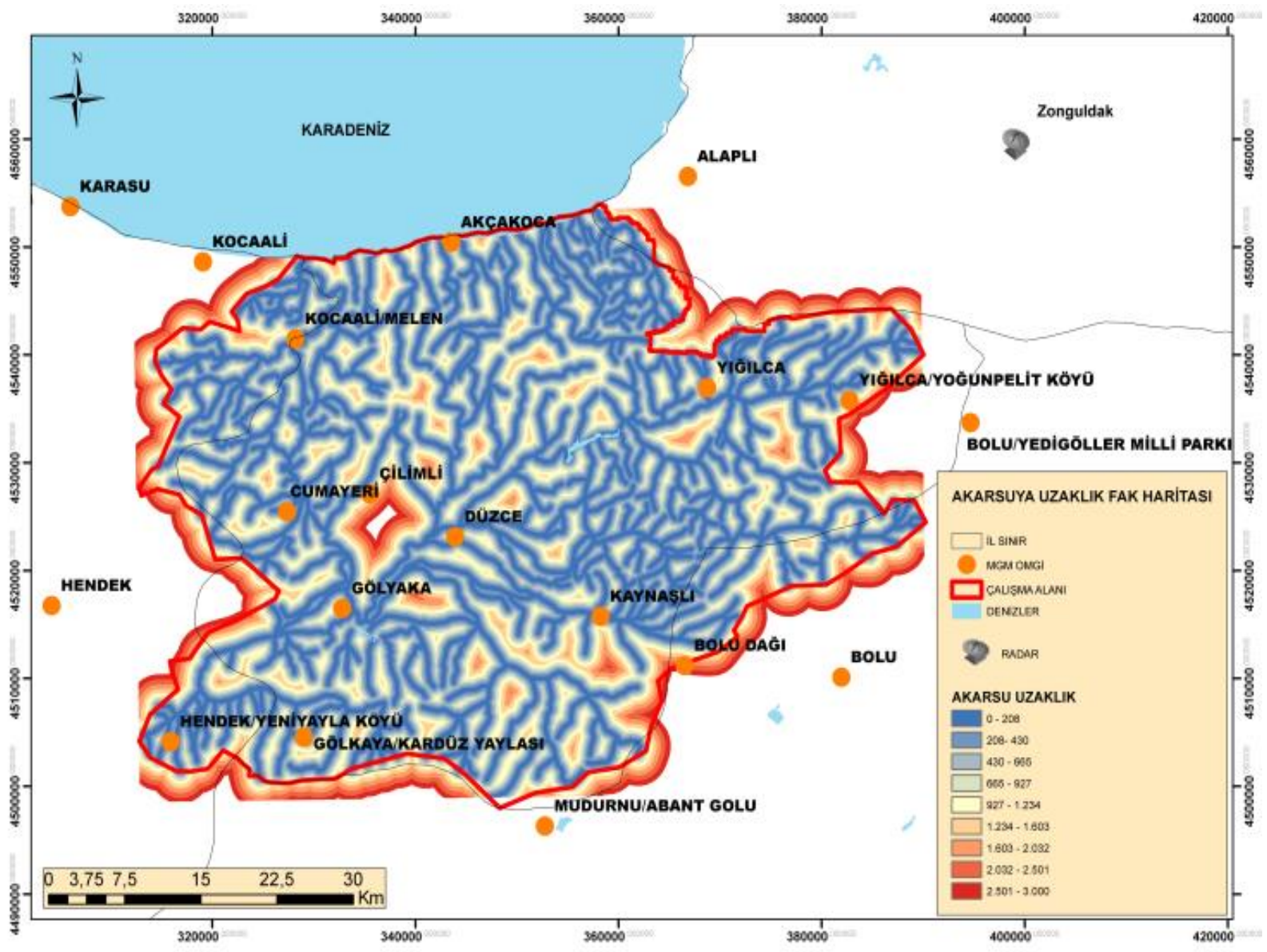

Şekil 7. Akarsuya Uzaklık Faktörü Haritası 


\subsection{Yağış faktörleri}

Taşkın duyarlılığı açısından en önemli faktörlerden birisi yağıș miktarıdır. Tașkının gerçekleșmesi ve büyüklüğü, direkt olarak yağışa bağlıdır. Çalışmada, 2 farklı yağıș ürünü kullanılmıștır. Bunlar:

- Meteoroloji Genel Müdürlüğü ölçüm verilerinden elde edilen maksimum yağıșların maksimumu,

-17-18 Temmuz 2019 tarihli MGM Zonguldak (ZNG) radarı SRI (Surface Rainfall Intensity) ürünleri kullanılarak elde edilmiș " $n$ " saatlik toplam yağıș değeri Radar RNN (RAINN) ürünüdür.

Yağış ürünleri ayrı ayrı çalışma alanında enterpole edilerek raster formatına dönüștürülmüştür.

\subsubsection{Otomatik meteoroloji gözlem istasyonu (OMGI)}

Sakarya ve Batı Karadeniz havzalarının birleşiminde yer alan çalışma alanı, Düzce iline bağlı Akçakoca, Kocaali/Melen, Çilimli, Cumayeri, Gölyaka, Yığılca,
Kaynaşlı ve Hendek ilçelerini kapsamaktadır. Belirlenen çalışma alanı ve çevresinde iklim özelliklerini oluşturan atmosferik bileșenler, Meteoroloji Genel Müdürlüğü ölçüm istasyonları tarafından ölçülmektedir. Çalışmada, Tablo 2'de bilgileri verilen MGM OMGİ istasyon verileri göz önüne alınmıştır. $\mathrm{Bu}$ istasyonlara ait maksimumların maksimum değeri baz alınarak, ArcGIS 10.3'de IDW (Inverse Distance Weighting) enterpolasyon yöntemi ile noktasal veriden alana yayılmış veri haline getirilmiştir.

Şekil 8'deki yağış dağılım haritası incelendiğinde, uzun yıllar maksimum yağış miktarının Düzce merkez, Cumayeri, Kaynaşlı ve Yığılca kesimlerinde ise 40-100 mm civarlarında olduğu görülmektedir. Kocaeli/Melen ve Akçakoca çevresinde uzun yıllar maksimum yağış miktarının ise $140 \mathrm{~mm}$ 'den fazla olduğu, özellikle Akçakoca kesimlerinde bu değerlerin 200 mm'den fazla olduğu görülmektedir. Bu değerler taşkın duyarlılığı açısından oldukça yüksektir. Şekil 8'de ayrıca Meteoroloji gözlem istasyonlarının konumları (turuncu renkli noktalar) olarak görülmektedir.

Tablo 2. Çalıșma Alanı ve Çevresindeki Bazı Meteoroloji İstasyonlarına Ait Karakteristik Bilgileri

\begin{tabular}{|c|c|c|c|c|c|}
\hline Enlem & Boylam & İstasyon No & İstasyon Adı & $\begin{array}{c}\text { Rakım } \\
\text { (m) }\end{array}$ & $\begin{array}{l}\text { MAK. } \\
\text { YAĞIŞ } \\
(\mathrm{mm})\end{array}$ \\
\hline 40,8203 & 31,742 & 19012 & BOLU/ÇELE ORMAN SAHASI & 1048 & 38,8 \\
\hline 40,7799 & 31,32007 & 19214 & KAYNAŞLI & 296 & 39,5 \\
\hline 40,9472 & 31,74871 & 19209 & BOLU/YEDİGÖLLER MİLLİ PARKI & 717 & 46,8 \\
\hline 40,7817 & 31,0186 & 18259 & GÖLYAKA & 118 & 56,8 \\
\hline 40,9642 & 31,6067 & 19017 & YIĞILCA/YOĞUNPELİT KÖYÜ & 741 & 58,8 \\
\hline 40,7329 & 31,6022 & 17070 & BOLU & 743 & 61,5 \\
\hline 40,8613 & 30,95177 & 19212 & CUMAYERİ & 140 & 65,6 \\
\hline 40,878 & 31,0483 & 19213 & ÇİLİMLİ & 158 & 68,4 \\
\hline 41,0219 & 30,55348 & 19119 & FERİZLİGÖLKENT BELDESİ & 48 & 76,8 \\
\hline 40,8437 & 31,1488 & 17072 & DÜZCE & 146 & 100,1 \\
\hline 41,1113 & 30,6901 & 17644 & KARASU & 4 & 101,6 \\
\hline 40,9725 & 31,44 & 18260 & YIĞILCA & 501 & 102,5 \\
\hline 40,7778 & 30,6797 & 18105 & HENDEK & 65 & 103,2 \\
\hline 40,6669 & 30,38222 & 18595 & HENDEK/YENIYAYLA KÖYÜ & 1080 & 104,2 \\
\hline 41,1486 & 31,4133 & 18265 & ALAPLI & 20 & 108,3 \\
\hline 40,7402 & 31,4191 & 17637 & BOLU DAĞI & 948 & 116 \\
\hline 41,0681 & 30,8469 & 18419 & KOCAALİ & 10 & 124,4 \\
\hline 40,6736 & 30,9772 & 18669 & GÖLYAKA/KARDÜZ YAYLASI & 1707 & 149,1 \\
\hline 41,0058 & 30,9572 & 18738 & KOCAALİ/MELEN & 126 & 176,4 \\
\hline 40,9339 & 30,4856 & 18416 & FERIZLİ & 45 & 196,7 \\
\hline 41,0895 & 31,1374 & 17015 & АКС̧АКОСА & 10 & 217,1 \\
\hline 40,6039 & 31,25972 & 18695 & MUDURNU/ABANT GÖLÜ & 1367 & 55 \\
\hline 40,4978 & 31,20444 & 18158 & MUDURNU & 785 & 47,2 \\
\hline
\end{tabular}




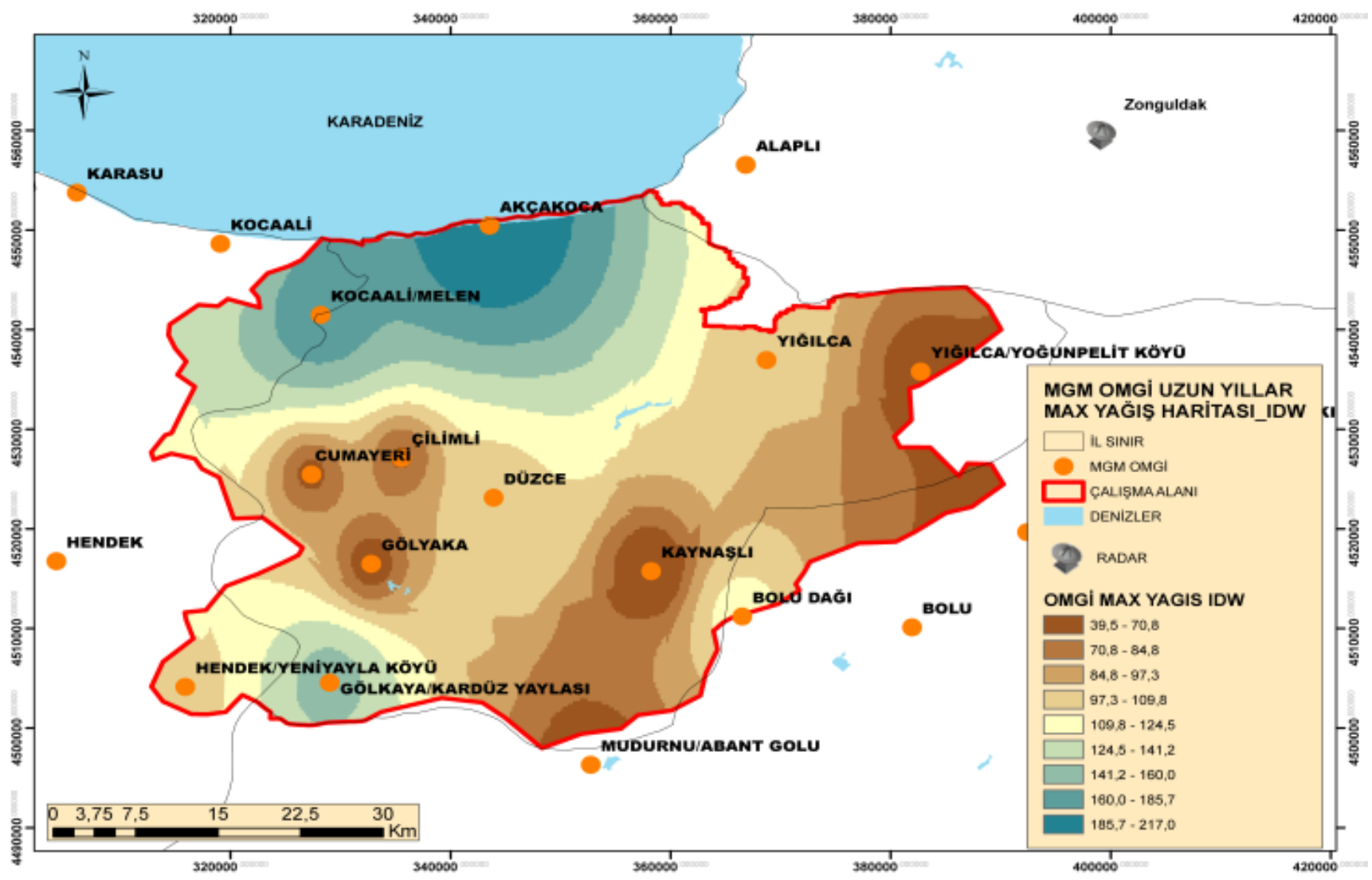

Şekil 8. MGM OMGİ Uzun Yıllar Maksimum Yağışların Maksimumu Haritası

\subsubsection{Meteorolojik Radar}

Çalışmada, ölçüm verilerinin dışında, ikinci senaryonun modellenmesinde kullanmak üzere 17-18 Temmuz 2019 tarihleri için meteoroloji radarı verileri kullanılmıştır. Meteoroloji radarları atmosfere belli frekansta elektromanyetik dalga gönderir ve bu dalgalar atmosferdeki hedeflerle etkileşerek saçılırlar. Meteoroloji radarları yağışı direkt olarak ölçmezler. Radar kapsama alanı içerisindeki hedefle etkileşen elektromanyetik dalganın saçılması ile radara geri dönen enerji (reflektivite) ișlenerek yağmur, dolu, kar, rüzgar, micro-macroburst, wind shear, türbülans gibi bir takım meteorolojik hadiselere ait bilgilere dönüștürülür. Reflektivite değerleri ampirik bağıntılar vasıtasıyla yağış miktarı bilgisine çevrilirler. Ülkemizde sel ve taşkın açısından yüksek riskli bölgeler bulunmaktadır. $\mathrm{Bu}$ bölgelere düşen yağış; bölgenin eğimi, arazi kullanımı, topografik özellikleri, toprak yapısı, bölgede gerçekleşen yağış sıklığı ve miktarı gibi nedenlerle, yere düşen yağışın hızla akışa dönüşmesiyle sel ve taşkınlara sebep olabilmektedir. Bu nedenle özellikle ülkemizde sel ve taşkın konusunda risk içeren bu bölgelerde yağış miktarının önceden tespit edilebilmesi, mevcut önlemlerin alınabilmesi için önem arz etmektedir. Meteoroloji radarları riskli bölgelere düşebilecek yağıș miktarını önceden tespit ederek, bu yağışlar sonucu oluşabilecek sel ve taşkın gibi hadiselerin tahmininde kullanılan erken uyarı sistemlerinde de kullanılmak amacıyla dünyanın birçok yerinde olduğu gibi ülkemizde de kullanılmaktadır (MGM, 2021b).

Yapılan bu çalışmada ÇKKV-AHY'de kullanmak için, 17-18 Temmuz 2019 tarihli MGM Zonguldak (ZNG) radarı SRI ürünleri kullanılarak elde edilmiş RNN (N saatlik toplam yağış) ürünleri kullanılmıştır. Zonguldak radarı 1108 rakım, 25m kule yüksekliğinde sahip tekli polarizasyon özellikli C band bir radardır. ZNG Radarının çalışma alanına göre konumu Şekil 10'da gösterilmiştir. 17-18 Temmuz tarihleri arasında Düzce ili ve ilçelerinde şiddetli yağış sonucu sel ve heyelan olayı gerçekleşmiştir. Sel hadisesinin şiddetinin en yoğun görüldüğü ilçe olan Akçakoca ilçesi ile ZNG radarı arasındaki görünürlük analizine bakıldığında, radar sinyalinin bölgeyi en alt tarama açısı olan $0^{\circ}$ ile herhangi bir işın engellenmesine maruz kalmadan sorunsuz bir șekilde gördüğü, Akçakoca ile ZNG radarı arasındaki uzaklığın $56.4 \mathrm{~km}$ olduğu ve minimum görülebilir ışın yüksekliğinin ise $1044 \mathrm{~m}$ olduğu görülmüştür. Akçakoca-ZNG radarı görünürlük analizi sonuçları Şekil 9'da ayrıntılı olarak görülmektedir.

17 Temmuz 2019 tarihi ZNG radarına ait 24 saatlik toplam yağış (RN24) ürünü haritaları Şekil $10^{\prime}$ da, 18 Temmuz 2019 tarihi ZNG radarına ait 24 saatlik toplam yă̆ış (RN24) ürünü haritaları ise Şekil 11'de gösterilmiştir. Şekil 10'a bakıldığında 17 Temmuz tarihinde Kocaeli/Melen civarında radardan elde edilen 24 saatlik maksimum toplam yağış 234 mm'dir. Şekil 11'deki RN24 ürünü haritasına bakıldığında ise; ayın 18'inde yağışın doğu yönünde ve etkisini arttırarak ilerlediği, özellikle Akçakoca ve Melen bölgelerinin yağıştan daha şiddetli etkilediği, 24 saatlik maksimum toplam yağıș $274 \quad \mathrm{~mm}$ civarında olduğu gözlemlenmektedir. Melen'den Cumayeri'ne doğru uzanan bölgedeki maksimum 24 saatlik toplam yağış değerinin ise $90-139 \mathrm{~mm}$ arasında olduğu görülmektedir. 
17015 - Akçakoca

Radar: ZONGULDAK

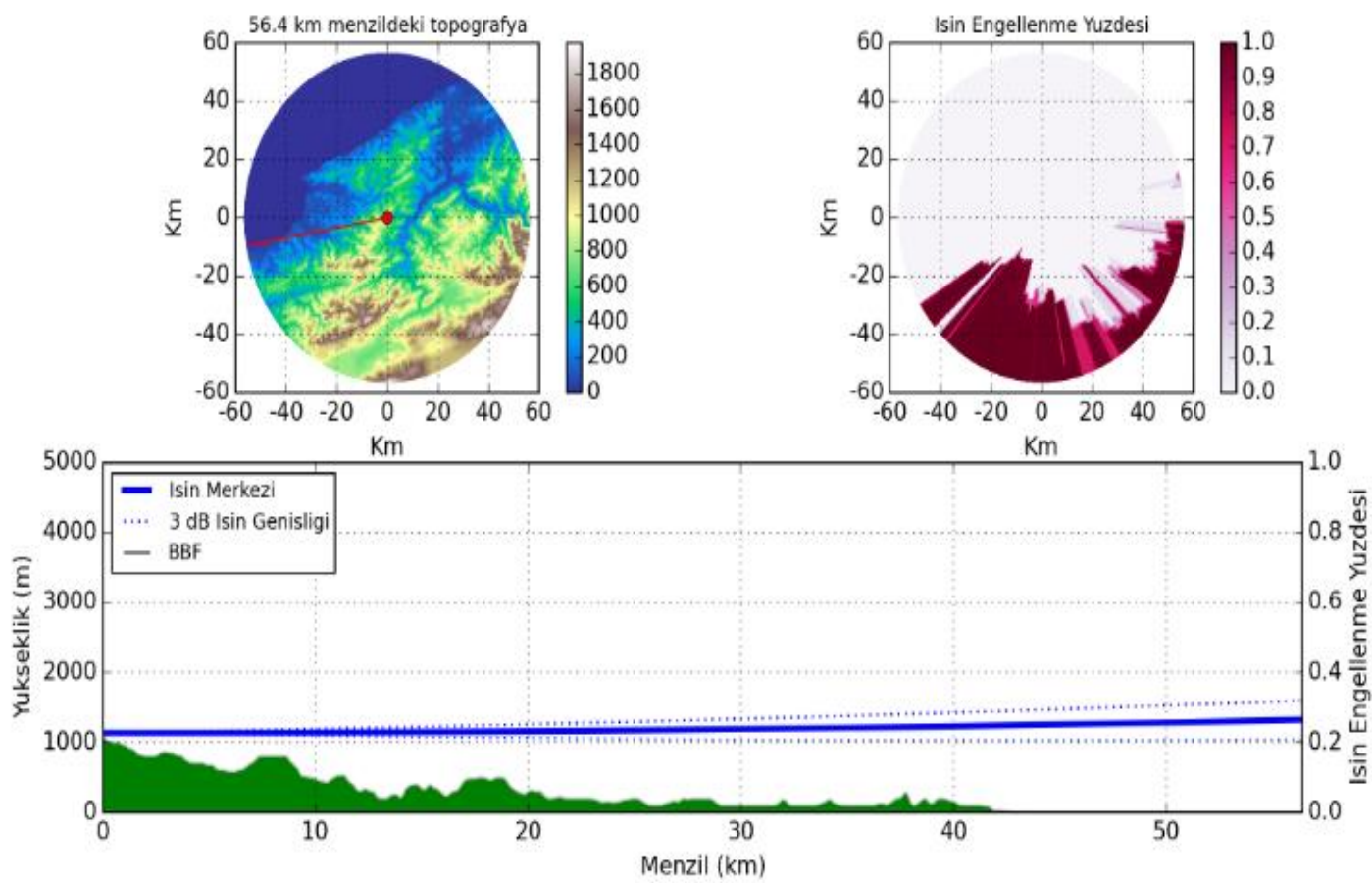

Gorunur Isinin Capi (Visible Beam Radius) : 550 metre

Gorunur Isinin Yuzdesi (Visible Beam Percentage): $100 \%$

Minimum Gorunur Isin Yuksekligi(MSL) (Minimum Height of Visibility): 1044 metre

Istasyon Yuksekligi (Station Altitude): 10 metre

Minimum Gorunur Aci (Minimum Visible Angle): 0 derece

Şekil 9. Akçakoca-ZNG Radarı Görünürlük Analizi

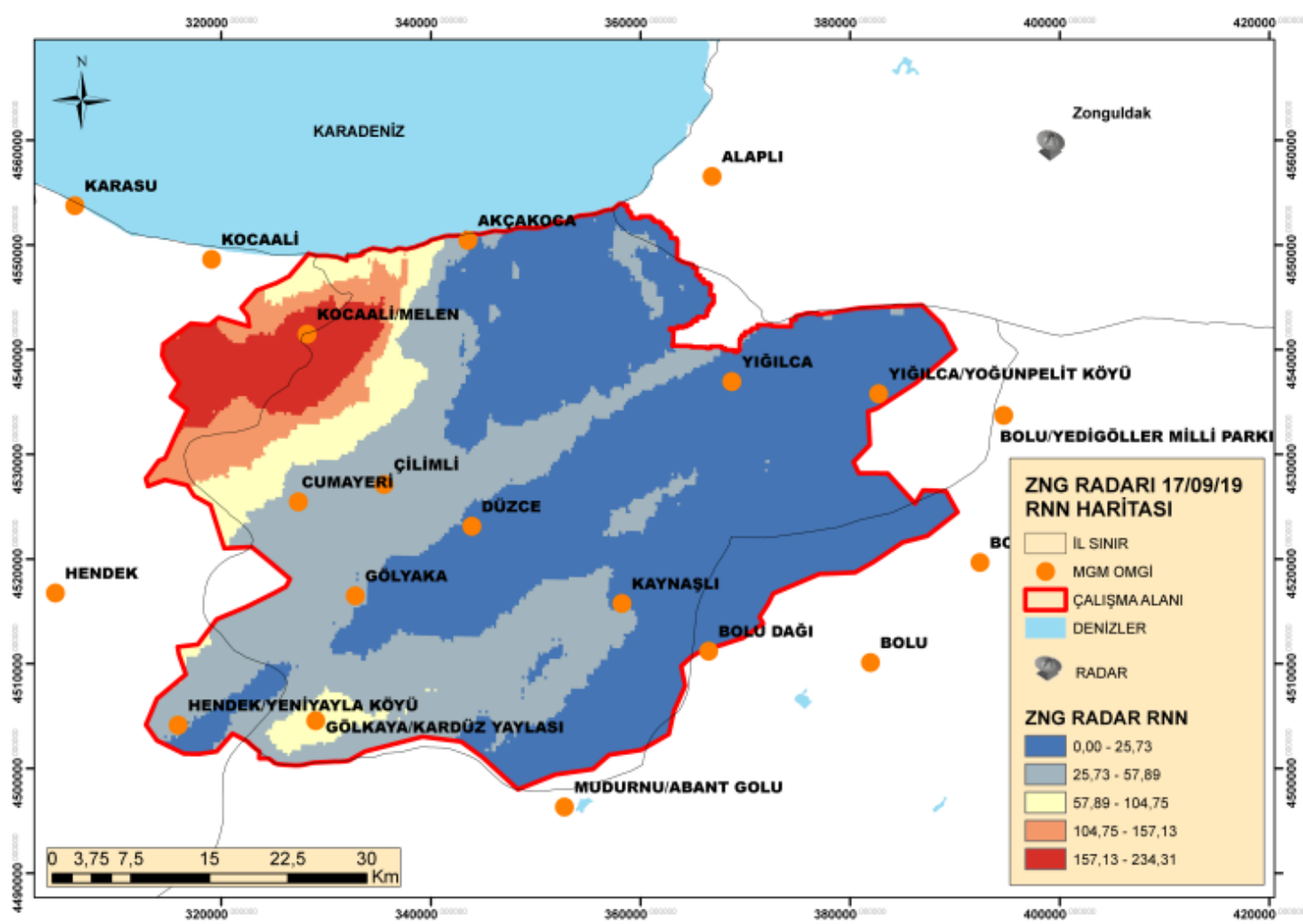

Șekil 10. Șekil 10. 17 Temmuz 2019 ZNG Radarı RN24 Ürünü Haritası 


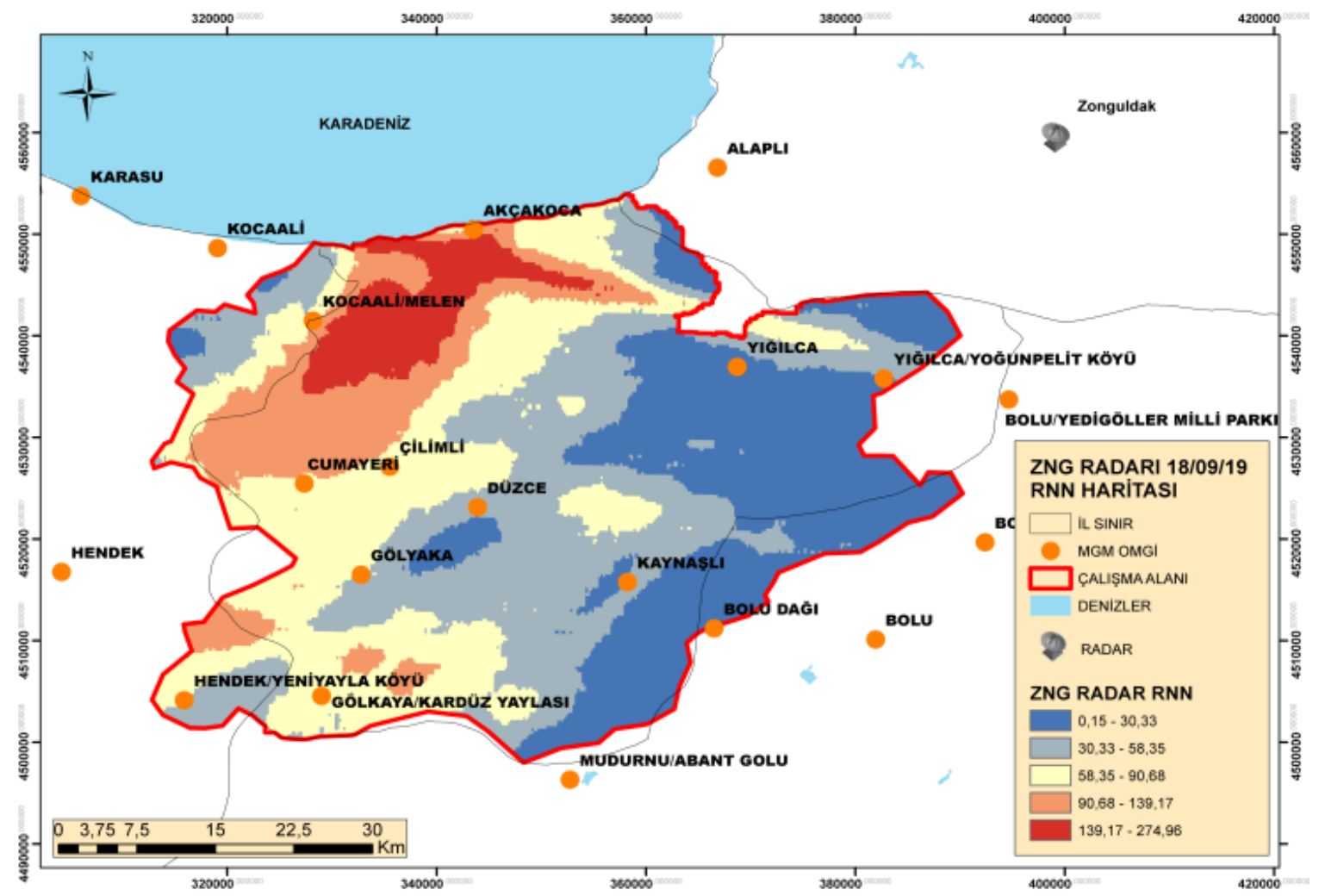

Șekil 11. Șekil 11. 18 Temmuz 2019 ZNG Radarı RN24 Ürünü Haritası

\section{Bulgular}

Çalışmada, Düzce bölgesinde taşkın duyarlılı̆g üzerinde etkili olan faktörler (eğim, arazi kullanım, toprak, bakı, jeoloji, akarsuya olan uzaklık, uzun yıllar maksimum yağış ve Radar RN24 yağış) ele alınarak ÇKKV-AHY yöntemi ile bölgede taşkın duyarlılık alanları iki farklı senaryoya göre tespit edilmiștir. Calıșmada öncelikle, yă̆ıș verisi olarak uzun yıllar yağıș ölçüm verileri kullanılarak modelleme yapılmıștır. Sonrasında, 17-18 Temmuz 2019 tarihinde Düzce'de yașanan taşkın döneminde meteorolojik radar ile elde edilen yağıș değerlerine göre tekrar modelleme yapılarak, yağıșa bağlı taşkın duyarlılık alanlarındaki gelişim izlenmiştir.

MGM OMGI uzun yıllar maksimum yağıș verileri ile oluşturulan taşkın duyarlılık haritasına göre, "Çok Yüksek" ve "Yüksek" tașkın duyarlılığına sahip alanların yerleşim bölgesi üzerinde kaldığı ve bu alanlar olası bir taşkında ve taşkın anında zarar görme olasılığı en yüksek yerler olarak belirlenmiştir. Çalışma alanının denize yakın kesimleri, Çilimli, Cumayeri, Gölyaka ve Düzce il merkezi çevresi, eğimin düşük ve tarım alanlarının yaygın olduğu bölgelerdir. Çilimli, Cumayeri, Gölyaka ve Düzce il merkezi'ne ek olarak, Akçakoca ve Yığılca ilçeleri civarının taşkın duyarlılığı açısından "Çok Yüksek" sınıfına girdiği görülmektedir (Șekil 12).

Düzce taşkınının yaşandığı 17 Temmuz 2019 ve 18 Temmuz 2019 tarihlerinde meteorolojik radar verileri ile oluşturulan taşkın duyarlılık haritaları sırasıyla Şekil 13 ve Şekil 14'de gösterilmiştir. Buna göre; yağıșın yoğun olduğu 17 Temmuz 2019 tarihinde Kocaeli/Melen bölgesinin taşkın duyarlılığının Şekil 12'e göre artış gösterdiği gözlemlenmiştir. 18 Temmuz 2019 tarihi radar yağıșları göz önüne alınarak elde edilen harita (Șekil 14) incelendiğinde ise, 18 Temmuz 2019 tarihinde yağış hücresinin şiddetini artırarak doğu yönünde ilerlemesi sebebiyle, Kocaeli/Melen, Akçakoca ve Cumayeri bölgelerinde taşkın duyarlılık alanlarında Şekil 12 ve Şekil 13'e göre artış olduğu gözlemlenmiștir.

\section{Sonuç}

Sonuç olarak bu çalışmada öncelikle, MGM OMGi verileri kullanılarak uzun yıllar yılda anlık maksimum yağıșların maksimumu hesaplanmıș ve diğer faktörler de göz önüne alınarak ÇKKV-AHY yöntemi ile Düzce bölgesinde taşkın duyarlılık alanları tespit edilmiştir. Bunun yanında, 17-18 Temmuz 2019 tarihinde Gölyaka, Kocaeli/Melen, Cumayeri ve Akçakoca ilçelerinde taşkın hadisesi meydana gelmiștir. $\mathrm{Bu}$ tarihlere ait meteorolojik radar yağış verileri ile tekrar modelleme yapılarak, taşkın duyarlılık alanlarının yağışa göre gelișimi izlenmiștir.

Sonuçta, uzun yıllar yağış verileri göz önüne alınarak oluşturulan haritaya göre Çilimli, Cumayeri, Gölyaka, Düzce il merkezi, Akçakoca ve Yığılca ilçeleri civarının taşkın duyarlılığı açısından "Çok Yüksek" sınıfına girdiği görülmüștür. Taş̧ın olayının gerçekleștiği 17-18 Temmuz 2019 tarihine ait meteoroloji radar verileri göz önüne alınarak olușturulan tașkın duyarlılık haritasına bakıldığında, taşkın duyarlılık alanlarının yağış șiddetine göre önemli değișiklik gösterdiği ve modelleme sonucu elde edilen tașkın duyarlılık haritasının tașkının yașandığı bölgeleri ișaret ettiği görülmüștür. Çalışmanın sonucunda, ÇKKV-AHY gibi istatistiksel yöntemler, CBS teknikleri ve radar ürünleri ile yapılan tespitlerin gerçekleșen taşkın hadiselerinin analizinde kullanılabilir olduğu görülmüștür. Bu çalışma aynı zamanda, meteorolojik radar ürünlerinin taşkın analizinde kullanılabilirliğinin yaygınlaştırılması açısından da önemli bir çalışmadır. 


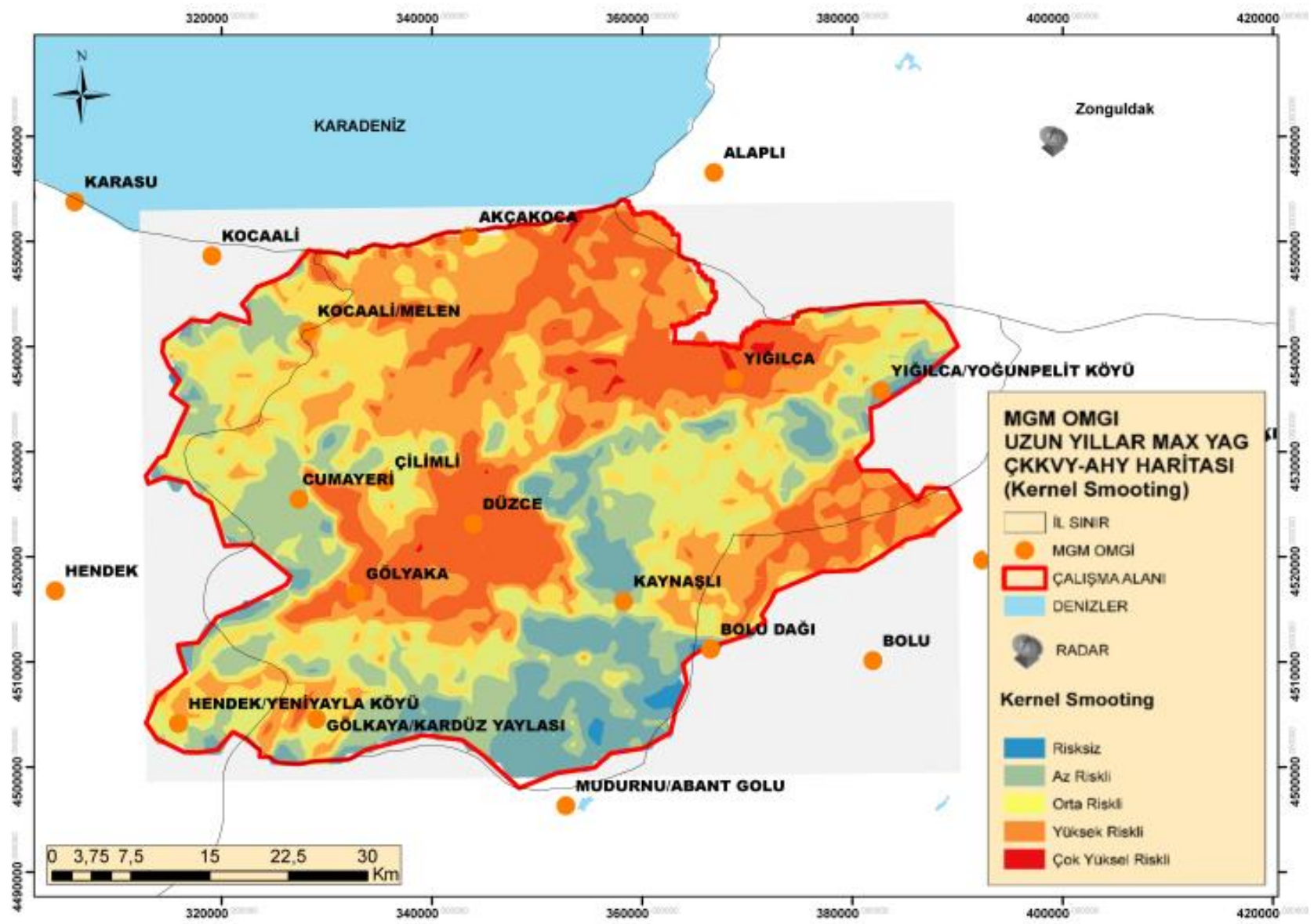

Şekil 12. MGM OMGI Uzun Yıllar Maksimum Yağış Verileri ile Modellenmiş Taşkın Duyarlılık Haritası

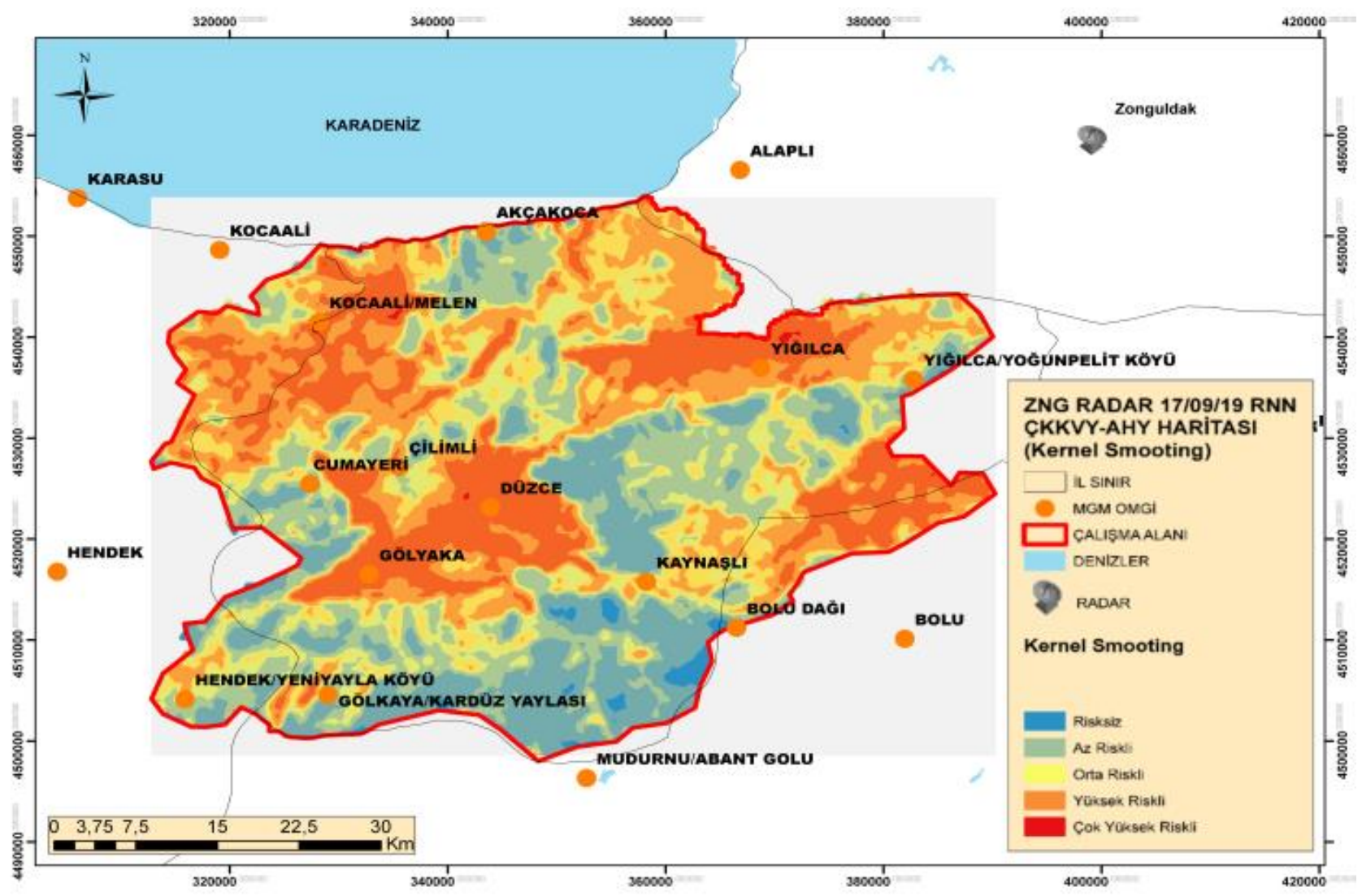

Şekil 13. 17 Temmuz 2019 Meteoroloji Radarı Yağış Verileri ile Modellenmiş Taşkın Duyarlılık Haritası 


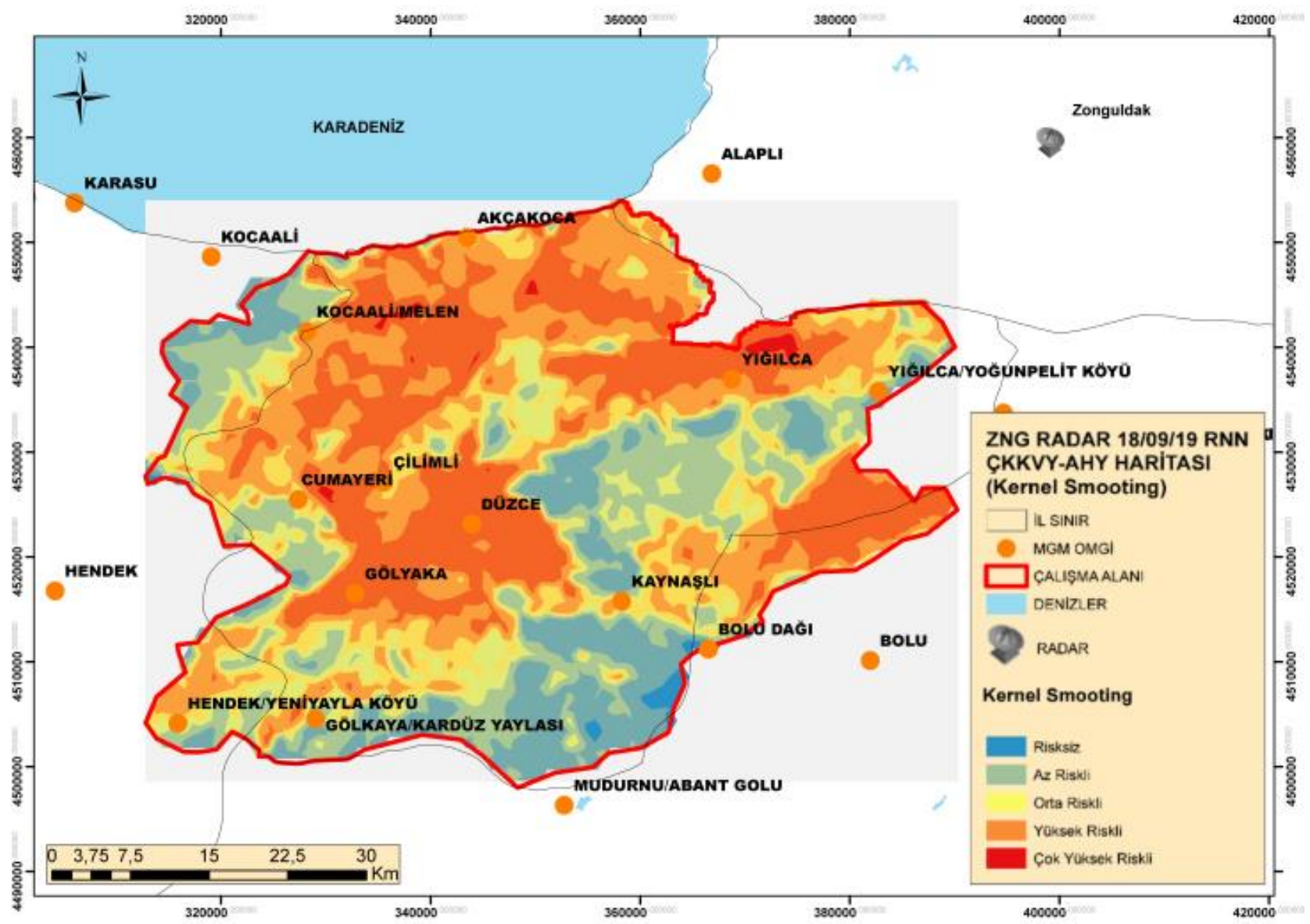

Şekil 14. 18 Temmuz 2019 Meteoroloji Radarı Yağış Verileri ile Modellenmiş Taşkın Duyarlılık Haritası

\section{Araştırmacıların katkı oranı}

Esin Oğuz: Literatür taraması, CBS Modelleme, Makale yazımı; Kahraman Oğuz: Literatür taraması, CBS Modelleme, Makale yazımı; Kurtuluş Öztürk: Radar verilerinin analizi, Makale yazımı

\section{Çatışma beyanı}

Herhangi bir çlkar çatışması bulunmamaktadır.

\section{Kaynakça}

Baysal G \& Tecim V (2009). Katı Atık Depolama Sahası Uygunluk Analizin Coğrafi Bilgi Sistemleri (CBS) Tabanlı Çok Kriterli Karar Yöntemleri ile Uygulaması. 4.Coğrafi Bilgi Sistemleri Bilişim Günleri, Fatih Üniversitesi, İstanbul.

Demir V \& Keskin A Ü (2022). Yeterince akım ölçümü olmayan nehirlerde taşkın debisinin hesaplanması ve taşkın modellemesi (Samsun, Mert Irmağı örneği). Geomatik, 7(2), 149-162.

Erten T \& Coşkun M Z (2010). Acil Durum Servislerinin Yer Seçimi: Analitik Hiyerarşi Yöntemi ve CBS Entegrasyonu. İtüdergisi/d Mühendislik, 9(6), 3750.

Ferreira F, Sevenhuysen P \& Treurnich J (1999). Satelliteearthobservationtodetect urban landusechange. 5 Ocak 2020 tarihinde http://www.ngo.grida.no/soesa/nsoer/issues/land/ inform.htm adresinden edinilmiștir.

Jansen L J M \& de Gregorio A (2004). Obtaining Landuseinformation from a remotely sensed land cover map: Results from a case study in Lebanon. International Journal of Applied Earth Observation and Geoinformation. 5(2), 141-157.

Kadıŏlu M \& Özdamar E (2008). Afet Zararlarını Azaltmanın Temel İlkeleri. Ankara: JICA Türkiye Ofisi Yayını (no:2).

Kadıoğlu M (2012). Türkiye'de İklim Değişikliği Risk Yönetimi, Türkiye Ulusal Bildirimi. Ankara: Çevre ve Şehircilik Bakanlığı Yayını.

Li X \& Yeh A G (2004). Analyzing spatial restructuring of land-use patterns in a fast growing region using remote sensing and GIS, Landscape and Urban Planning, 69(4), 335-354.

Lillesand M T \& Kiefer W R (2000). Remote Sensing and Image Interpretation, New York: John Wiley\&SonsPublication.

Meteoroloji Genel Müdürlüğü (MGM) 2021a. İllere Ait Mevsim Normalleri (1981-2010). 12 Temmuz 2021 tarihinde

https://www.mgm.gov.tr/veridegerlendirme/il-veilceler-istatistik.aspx?m=DUZCE adresinden edinilmiştir.

Meteoroloji Genel Müdürlüğü (MGM) 2021b. Meteoroloji Radarı Nedir? 13 Temmuz 2021 tarihinde https://www.mgm.gov.tr/genel/meteorolojiradarlar i.aspx?s=alanlar adresinden edinilmiştir. 
Oğuz K, Oğuz E \& Coşkun M (2016). Coğrafi Bilgi Sistemleri ile Taşkın Risk Alanlarının Belirlenmesi: Artvin İli Örneği. 4. Ulusal Taşkın Sempozyumu, 2325 Kasım 2016, Recep Tayyip Erdoğan Üniversitesi, Rize.

Özaslan M, Erşahin G, Akkahve D \& Sabuncu A (2001). Düzce İl Raporu, Düzce: Devlet Planlama Teşkilatı Yayını.

Özcan Ö (2008). Sakarya Nehri Alt Havzası'nın Taşkın Riski Analizinin Uzaktan Algllama ve CBS ile Belirlenmesi, Doktora Tezi, Bilișim Enstitüsü, İstanbul Teknik Üniversitesi, İstanbul.

Özalp D (2009). Dere Taşkın Risk Haritalarının CBS Kullanılarak Oluşturulması ve CBS İle Taşkın Risk Analizi, Doktora Tezi, Geomatik Mühendisliği, Fen Bilimleri Enstitüsü, İstanbul Teknik Üniversitesi, İstanbul.

Özcan Ö, Musaoğlu N \& Şeker D Z (2009). Taşkın Alanlarının CBS ve Uzaktan Algılama Yardımıyla Belirlenmesi ve Risk Yöntemi: Sakarya Havzası Örneği. TMMOB Harita ve Kadastro Mühendisleri Odası 12. Türkiye Harita Bilimsel ve Teknik Kurultayı, 11 - 15 Mayıs 2009, Ankara.

Özcan $O$ (2017). Taşkın Tespitinin Farklı Yöntemlerle Değerlendirilmesi: Ayamama Deresi Örneği. Artvin Coruh Üniversitesi Doğal Afetler ve Çevre Dergisi, 3(1), 9-27.

Özdemir H (2007). Farklı Senaryolara Göre Taşkın Risk Analizi: Havran Çayı Örneği (Balıkesir). TMMOB Afet Sempozyumu, 5-7 Aralık 2007, Ankara.
Özer Z (1990). Su Yapılarının Projelendirilmesinde Hidrolojik ve Hidrolik Esaslar (Teknik Rehber), Ankara.

Özşahin E (2013). Arnavutluk'ta Taşkın Risk Analizi. Uluslararası Avrasya Sosyal Bilimler Dergisi, 4(12), 91-109.

Öztürk D (2009). CBS Tabanlı Çok Ölçütlü Karar Analizi Yöntemleri ile Sel ve Taşkın Duyarlılığının Belirlenmesi: Güney Marmara Havzası Örneği, Doktora Tezi, Fen Bilimleri Enstitüsü, Yıldız Teknik Üniversitesi, İstanbul.

Öztürk D \& Batuk F (2011). SCS yüzey akıș eğri numarasının uzaktan algılama ve coğrafi bilgi sistemleri ile belirlenmesi. TUFUAB V. Teknik Sempozyumu, 23-25 Şubat 2011, Antalya.

Sunkar M \& Tonbul S (2010). İluh Deresi Havzası'na (Batman) Yönelik Sel ve Taşkın Riski Analizleri. eJournal of New World Sciences Academy, 5(4), 255273.

Şen Z (2009). İklim Değişikliği İçerikli Taşkın Afet ve Modern Hesaplama Yöntemleri, Su Vakfı Yayınları.

Yaralıoğlu K (2004). Analitik Hiyerarşi Proses, Uygulamada Karar Destek Yöntemleri, İlkem Ofset, İzmir, 2004. 